\title{
シンポジウム(9) 耳鼻咽喉科の新規医療
}

\author{
司会のことば \\ 塩谷 彰浩 \\ 防衛医科大学校 耳鼻咽喉科学 \\ 本間 明宏 \\ 北海道大学 医学部 耳鼻咽喉科・頭頸部外科学
}

医療技術の進歩はめざましく、耳鼻咽喉科・頭頸部外科領域においても、新しい検查法、治療法が次々と導入されて います。

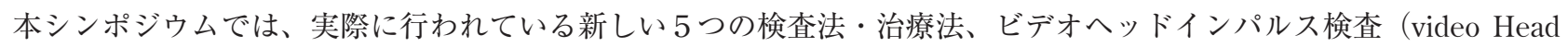
Impulse Test：vHIT)、耳管ピン、ロボット手術、閉塞性睡眠時無呼吸症（Obstructive Sleep Apnea：OSA）に対する 舌下神経刺激療法、がんゲノム医療について日本の第一人者の先生方に述べていただきます。

池園哲郎先生には半規管本来の機能である頭部回転による半規管性動眼反射を測定するvHITについて述べていただ きます。ベッドサイドでも簡単に行うことができ、諸外国では病変の局在診断に役立つ半規管機能検査として普及して おり、日本でも医療機器認証されている検査です。

大島猛史先生には耳管ピンについて括ししていただきます。耳管ピンは、耳管開放症に対して中耳経由で耳管に挿 入するもので、2017年に行われた医師主導治験で $82.1 \%$ 有効率が得られ、近い将来の薬事承認が見込まれています。

楯谷一郎先生のテーマはロボット手術です。初期の中咽頭癌に対するロボット手術はすでに海外では広く行われてお り、日本もようやく導入されつつあります。日本のトップランナーとして本邦のロボット手術の現状と将来について述 ベていただきます。

中島逸男先生には OSA の新規治療である舌下神経刺激療法について紹介していただきます。海外では、2014年から 約5,000人の患者に行われ、持続陽圧呼吸療法 (Continuous Positive Airway Pressure: CPAP) 不認容な中等症から重 症 OSA における二次的な治療法として期待されております。

平沢 晃先生にはがんゲノム医療について述べていただきます。2019年より遺伝子パネル検査に関連した診療の一部 が保険収載され、がんの領域ではゲノム医療が実際の診療に導入され、今後、さらに大きく発展すると予想されます が、がんゲノム医療の現状と問題点を考えたいと思います。

5つの検查法・治療法は、一般に広く行われていない方法もありますが、近い将来、普及すると期待されるものばか りで、本シンポジウムは耳鼻咽喉科・頭頸部外科領域の時代の最先端を知る良い機会になると思います。多くの会員の みなさまの聴講を期待しております。 
ビデオヘッドインパルス検査（video Head Impulse Test）

池園＼cjkstart哲郎

埼玉医科大学

（背景）ヘッドインパルス検査（head impulse test；HIT）は頭部回転刺激による検査で半規管性動眼反射（vestibulo-ocular reflex；VOR）を測定する。ベッドサイドでも簡単に行うことができ、諸外国では半規管機能検査として普 及している。

HIT では、被験者に視標（検者の鼻先や目など）を注視させた状態で、頭部を受動的かつ急速に $5^{\circ} \sim 10^{\circ}$ 回旋させ る。head impulse とはこの急速な頭部回転のことを指す。VORが正常であれば、前庭眼反射が働き視標を注視できる。 機能が低下すると、十分な VORが働かず視線の位置と視標にズレが生じる。これを補正して視標を捉えるために急速 眼球運動が生じるが、これが catch up saccade (CUS) と呼ばれるものである。CUS を肉眼で確認した場合に半規管機 能低下ありと判定する。例えば左耳を後方に水平方向へ回転させる head impulse を加えた際にCUSがあれば左外側半 規管機能低下と判断する。

HIT は半規管本来の機能である頭部回転によるVORを検査できるという大きな利点がある。欠点は、検者が検查技 術に習熟する必要があることと、検査結果の判定が主観的であること、カロリックと比較して検出感度が低いことなど が指摘されている。近年、これらの欠点を軽減したvideo HIT が開発された。肉眼で検出しづらいCUSでも正確に検 出できるだけでなく、左右それぞれの VOR gain の平均值を算出し機能低下を定量的に評価できる。現在では前者は clinical HIT (cHIT)、後者はvHIT と呼ばれており、比較を表に示す。日本では 2 機種が医療機器認証されている。

(臨床的意義) 半規管によるVORの神経経路の機能障害の診断に役立つ。末梢病変においては、6つのすべての半 規管の機能を評価する検査として用いられ、患側の決定、障害部位、責任半規管を明らかにする検査として用いられ る。外側半規管、前半規管は半規管一上前庭神経系の障害を示唆する。後半規管は半規管一下前庭神経系の障害を示唆 する。VOR gain は、ほほ年齢の影響を受けず高齢者でも保たれる。

さらにcHIT、vHIT は Acute vestibular syndrome(AVS) の鑑別に有用とされている。中枢性 AVS の場合にはVOR gain が正常な場合が多いことを利用して、HINTS(HI：Head Impulse, N：Nystagmus direction and TS：Testing Skew.) という末梢性 AVS、中枢性 AVS の鑑別診断アルゴリズムが報告されている。ある一定の inclusion criteriaのもとでは 感度 $100 \%$ 特異度 $96 \%$ と極めて高い診断精度を持つ。HIT と臨床所見を総合的に検討することで病変の局在診断に役立 つ。

表 各種半規管機能検查の比較

\begin{tabular}{llll}
\hline & 温度刺激検査 & \multicolumn{1}{c}{ HIT } & \multicolumn{1}{c}{ vHIT } \\
\hline \multicolumn{1}{c}{ 刺激方法 } & \multicolumn{1}{c}{ 温度 } & \multicolumn{1}{c}{ 回転 } & \multicolumn{1}{c}{ 回転 } \\
\hline 一側の刺激回数 & 1 回 & 3 回以上 & 20 回以上 \\
検査時間 & 長い & 短い & 短い \\
定量化 & できる & できない & できる \\
主観 & 入らない & 入る & 入らない \\
検査場所 & 多くは固定 & 移動可能 & 移動可能 \\
煰気 & 生じ得る & 生じない & 生じない \\
耳の形態 & 影響受ける & 影響受けない & 影響受けない \\
Covert CUS の検出 & & できない & できる \\
\hline
\end{tabular}

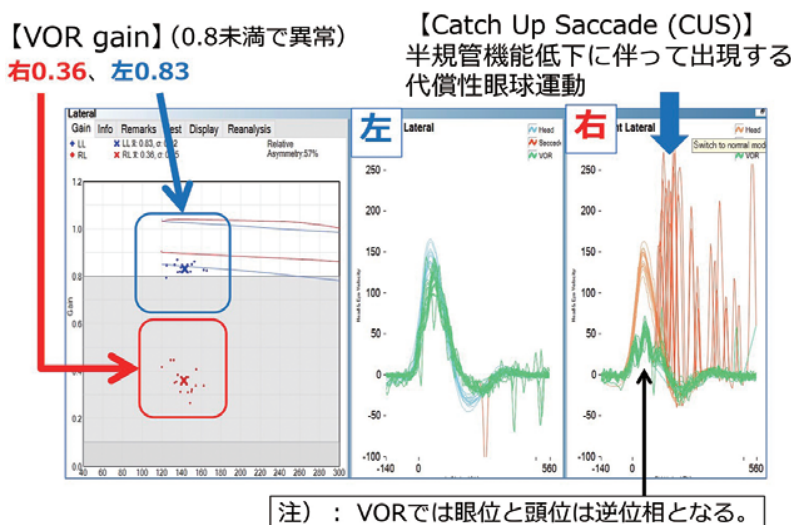

：VORでは眼位と頭位は逆位相となる。 この図では眼位を反転して表示されている

図 検査結果例 


\title{
耳管ピン
}

\author{
大島 猛史 \\ 日本大学 医学部 耳鼻咽喉・頭頸部外科
}

耳管開放症は自声強聴、耳閉感、自己呼吸音聴取を主症状とする疾患であり、日常診療の現場でよく遭遇する。本邦 では診断基準が整備され、その病態が周知されるようになった。耳管開放症の原因、誘因は多様であり、また、症状の 程度もほとんど無症状から日常生活に著しい障害を来すものまで範囲が広い。重症例の治療に難渋する一方で、症状が 軽度で現状の説明を丁寧に行い対処法を指示するだけで特段の治療が必要ない例や、自然に軽快していく例もある。そ のため、重症度を的確に判断し、予後を診断することが重要である。保存的治療が原則であるが、改善しない例が少な からずあり、そのような例では耳管ピン挿入術をはじめとした手術的治療が考慮されることになる。

耳管ピンは2017年に医師主導治験が行われ、近い将来の薬事承認が見込まれている。今後、保険収載されると多くの 医療機関で手術が施行されると考えられるが、これまでは限られた施設で研究目的あるいは自費診療として行われてき た。日本大学医学部附属板橋病院では2014年12月に耳管外来を開設後、薬事未承認の耳管ピンを取り扱うための学内審 査を経て2015年11月から自費診療として耳管ピン挿入術を開始した。2019年12月まで110例127耳に手術を行い、121耳 に留置した。なお、当科では日帰り手術として行っている。

耳管ピン挿入術は鼓膜麻酔（イオントホレーゼ）下に行う。残存麻酔液を吸引除去したのちに前上象限を鼓膜切開す

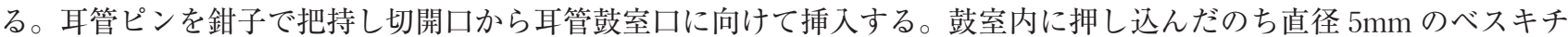
ン片で鼓膜切開口を被覆して終了する。材質はシリコン製で体部先端横径が 1 ～ $3 \mathrm{~mm}$ 、尾部に近づくに従い幅が広くな る。鼓膜切開口から耳管へ挿入しやすくするため先端はわずかに弯曲している。

耳管ピンは耳管開放症のすべてが適応になるわけではない。医師主導治験では、(1) 耳管開放症確実例と診断され、 (2) 保存的治療で改善せず症状が 6 カ月以上続き、(3) PHI10 スコアが26点以上（重症例）のすべてを満たす症例が手術 適応とされた。なお、唯一聴耳は適応外である。当科でもそれに準じているが、PHI10 は患者の主観が大きく左右する 尺度であるため26点未満の症例でも手術を施行している。

術前には基本的にCT を施行している。頸動脈管骨壁の欠損、内頸動脈走行異常がある場合はピン挿入に際して危険 を伴う可能性がある。これまで耳管ピンの挿入・留置に伴う内頸動脈の損傷の報告はないが、耳管ピンは長期にわたり 留置されるので、術前 $\mathrm{CT}$ で内頸動脈の走行、骨壁欠損の有無を確認している。また、耳管骨部の形状は周囲蜂巣の発 育や内頸動脈の走行に影響されバリエーションが大きい。耳管周囲蜂巣への誤挿入を避けるためにもCTで耳管鼓室口 をイメージしている。ただし、これまで術前 CT 所見により手術を断念したことはない。

主な合併症は滲出性中耳炎と鼓膜穿孔残存である。医師主導治験ではそれぞれ $17.2 \% 、 13.8 \%$ あった。東北大での 252 耳での検討ではそれぞれ14.7\%、19.8\%にみられた。当科でも13.3\% (チューブ留置例)、16.7\%であった。これま で重篤な術後出血はなかった。手術操作により外耳道皮膚を擦過することがあるため外耳道出血は経験したが、鼓室内 からの出血はなかった。出血傾向についてはバイアスピリン内服程度では手術施行にはほとんど影響はないと考えてい る。肝硬変に伴う出血傾向例、ワーファリン内服例が各 1 例あった。

耳管ピン挿入術は低侵襲で簡便な手術であり、有効率も高く、医師主導治験では $82.1 \%$ あっった。インターネットな どの情報環境の下で患者の期待も高い。当科では観察期間中に 8 例 $(6.3 \%)$ 抜去したが、これは患者の過大な期待を 優先させたことが大きな要因であると考えている。耳管開放症を的確に診断しその適応の可否を判断しなければよい結 果は得られない。近い将来の普及を鑑み、トラブル時の対処法を含め、この点についてはさらに検討を深めることが必 要と考えている。 


\title{
頭頸部外科領域におけるロボット支援手術
}

\author{
楯谷 一郎 \\ 藤田医科大学 耳鼻咽喉科・頭頸部外科
}

頭頸部には咀嚼・嚥下などの人間が生きる上で必要な機能に加え、発声・味覚・聴覚など社会生活を送る上で重要な 機能が集中しており、また顔面・頸部という露出した部位がかかわるため、頭頸部がんの治療に際してはこれらの機能 の温存や整容的な配慮が欠かせない。口などの natural orifice あるいは小さな皮膚切開から低侵襲治療を行えるロボッ 卜支援手術は、頭頸部がん治療において極めて相性の良い治療方法であり、咽喉頭がん・甲状腺がんを主対象に術式が 開発され、普及しつつある。

咽頭がん・喉頭がんの治療に際しては、癌の制御のみならず治療後の嚥下・発声機能を如何に温存するかが肝要であ る。経口的に咽頭がん・喉頭がんを摘出する低侵襲手術として、1990年前後より経口的レーザー手術（Transoral laser microsurgery）が開発され、局所制御のみならず嚥下機能においても良好な成績が報告された。顕微鏡下の経口的手術 では一度に直視できる視野が狭いため、分割切除を余儀なくされるなどの技術的な問題があり、広く普及するには至ら なかったが、2000年代に入って手術支援ロボット・ダビンチサージカルシステム（以下ダビンチ）が登場し、経口的ロ ボット支援手術（Transoral Robotic Surgery：TORS）が開発された。

経口的ロボット支援手術では、開口器により咽頭・喉頭の術野を展開し、1 本の $3 \mathrm{D}$ 内視鏡と 2 本の操作用鉗子 （Endowrist）を保持した計 3 本のロボットアームを経口的に挿入して、病変を切除する。術野に近接した鮮明な $3 \mathrm{D}$ 画 像を得ることができ、さらに自在に先端が曲がる鉗子により、従来では切除が困難であった咽喉頭がん病変の切除が可 能である。経口的手術では皮膚に孔を開ける必要がないこと、解剖学的に複雑で狭い咽喉頭の中で自在に鉗子を操作で きる手術支援ロボットのメリットが生きることから、咽頭がん・喉頭がんは手術支援ロボットの最も良い適応の一つと されている。咽頭がん・喉頭がんでは手術と放射線治療の両者が標準治療として使用されているが、米国の National Cancer Data Base での中咽頭がん T1、T2（8,768例）に対する治療法の統計では、2004年には手術の割合が56\%、放 射線治療の割合が44\%であったのに対し、2013年には手術が $82 \%$ と、経口的ロボット支援手術の登場により中咽頭癌治 療のパラダイムシフトがおきている。また、2018年には経口的ロボット支援手術に適した単筒式のダビンチ Spがアメ リカで発売されており、咽喉頭手術における利点が報告されている。

本邦では耳鼻咽喉科領域はダビンチの適応外であったが、2015〜2016年に先進医療 B として東京医科大学、鳥取大 学、京都大学で多施設臨床試験が実施され、2018年 8 月に頭頸部外科領域（経口的に行う手術に限る。）が薬機法上の 適応として承認された。現在は、国内における経口的ロボット支援手術の安全な普及ならびに今後の保険収載を目指し て体制が整備されており、日本耳鼻咽喉科学会承認の下、日本頭頸部外科学会によって術者の資格基準・施設要件など を定めたロボット支援手術にかかわる指針ならびにロボット支援手術教育プログラムが作成され、2019年 4 月より実施 されている。

甲状腺がん治療の第一選択は手術であるが、女性に多く発症することもあり、約 20 年前より、内視鏡を補助的に用い て創部を極力小さくしたり、露出部以外に皮膚切開をおいてすべての操作を内視鏡下に行うなど、術後の審美面での改 善を目的にさまざまな内視鏡下甲状腺手術が開発されてきた。また、ダビンチの登場と共に韓国を中心として甲状腺手 術に手術支援ロボットが応用され、海外では high volume centerを中心に多くの手術がなされている。術野の展開方法 としては二酸化炭素ガスを送気して頸部皮膚を持ち上げ術野を確保する術式と、鈎で皮膚を吊り上げて術野を確保する 術式に大別され、腋窩、耳後部、また近年では口腔前提に切開をおいて操作を行うアプローチ方法が報告されている。

本シンポジウムでは咽頭がん・喉頭がん・甲状腺がんに対するロボット支援手術の発展ならびに国内外の現状につい て述べたい。 


\title{
舌下神経刺激療法
}

\author{
中島 逸男 \\ 獨協医科大学 医学部 耳鼻咽喉・頭頸部外科 \\ 睡眠医療センター
}

\begin{abstract}
いびきや閉塞性睡眠時無呼吸症（Obstructive Sleep Apnea：以下 OSA）に対する外科的アプローチは1961年に池松が いびきに対する咽頭腔拡張術を開発し1)、1981年に Fujita ら ${ }^{2)}$ が池松の術式から OSA に対する治療として口蓋垂口蓋咽 頭形成術（以下 UPPP；Uvulo-Palato-Pharyngo-Plasty）を報告したことで世界的に広まったことは周知の通りである が、その手術適応について十分な検討がなされることなく数多く行われたこともあり、効果不十分と判定される例や術 後合併症が問題となった ${ }^{3)}$ 。また Fujita らの UPPPの報告と時を同じくして、Sullivan ら の gold standard である経鼻的持続陽圧換気（以下 nCPAP; nasal continuous positive airway pressure）療法の有用性か 報告された。nCPAP は空気圧による上気道開存を可能にし、生命予後の向上に寄与すると報告されている。興味深い ことに nCPAP と UPPP の長期生存率に関する報告 ${ }^{5}$ では、nCPAP と UPPP はほほ同等の治療効果を有しているとされ る。すなわち CPAP は (治療) 効率 Efficiency は極めて高いものの、その使用率が 50 ～60\%相当であることを加味する と、その (治療) 効果 Effectiveness は中程度となる。それに対し外科的手術は効率 Efficiencyにばらつきを認めるが、
\end{abstract} 治療効果の高い患者だけを治療できれば、Efficiency は CPAPよりも高くなることが期待される。

現在では OSA は多因子疾患であると考えられており、その病態を理解するうえで、Wellman ら ${ }^{6)}$ の考える OSAの病 因モデルには、上気道の解剖学的要因のほかに咽頭虚脱時の咽頭開大筋の反応の低下、呼吸中枢の不安定性・高いルー プゲイン、低い覚醒閾值の生理学的要因が挙げられている。実際には、これらの 4 つの要因が複雑に絡み、さらに個体 差もあるため、耳鼻咽喉科医による上気道の的確な診断・各病因病態生理に応じた治療介入が期待されている。

国外においては2014年から OSAの新規治療のひとつとして舌下神経刺激療法（HGNS; Hypoglossal Nerve Stimulation）が導入され7)、すでに約 5,000 人の患者に刺激装置の植え达みがされており、CPAP 不認容な中等症から重症 OSA における二次的な治療法として位置づけられている。本治療法は吸気時の舌の前方移動だけでなく、舌および舌骨上筋 群の収縮をもたらすことから、Wellman ら $^{6)}$ の考える咽頭虚脱時の咽頭開大筋の反応閾值の変化にも耐え得るデバイス として期待される。また、実際の植え込みでは舌下神経を露出させ、神経に刺激リードの電極力フを装着し、本体を鎖 骨下に留置するなど頭頸部領域に精通した手術経験が求められるため、今後耳鼻咽喉科医による Sleep Surgeryの新た な分野となると思われる。すでに欧米では術後 5 年以上経過した長期成績の結果も報告されており、RCTのデー夕も 集積されている。本シンポジウム「耳鼻咽喉科の新規医療」として Sleep Surgeryにおける舌下神経刺激療法について 文献的考察を加えて概説する。

文献

1）池松武之亮：いびきの研究＼cjkstart第 4 報，いびきの 2 治療法. 日耳鼻 $1961 ; 64: 434-435$.

2) Fujita S, Conway W, Zorick F, et al: Surgical correction of anatomic azbnormalities in obstructive sleep apnea syndrome: uvulopalatopharyngoplasty. Otolaryngol Head Neck Surg 1981; 89 : 923-934.

3) Kezirian EJ, Weaver EM, Yueh B, et al: Incidence of serious complications after uvulopalatopharyngoplasty. Laryngoscope $2004 ; 114$ : 450-453.

4) Sullivan CE, Issa FG, Berthon-Jones M, et al : Reversal of obstructive sleep apnoea by continuous positive airway pressure applied through the nares. Lancet $1981 ; 1: 862-865$.

5) Keenan SP, Burt H, Ryan CF, et al: Long-term survival of patients with obstructive sleep apnea treated by uvulopalatopharyngoplasty or nasal CPAP. Chest 1994 ; 105 : 155-159.

6) Wellman A, et al: A method for measuring and modeling the physiological traits causing obstructive sleep apnea. J Appl Physiol 2011; 110 : 1627-1637.

7) Strollo PJ, Soose RJ, Maurer JT, et al : Upper-airway stimulation for obstructive sleep apnea. N Engl J Med 2014 ; 370 : 139-149. 


\section{がんゲノム医療}

平沢 晃

岡山大学大学院＼cjkstart医歯薬学総合研究科＼cjkstart臨床遺伝子医療学

ゲノム医学の急速な発展は医学研究および医療分野に大きな発展をもたらしてきた。がんゲノム医療では、従来から の大規模臨床試験に基づいた標準治療とともに、がん組織や細胞を用いたクリニカルシーケンスの結果同定されたゲノ ムプロファイルに応じた個別化治療戦略を構築することを目指している。本邦の実地臨床においても着実に導入されて きており、厚生労働省は2018年にがんゲノム医療中核拠点病院・拠点病院・連携病院を指定して、がんの個別化診断・ 治療に向けた遺伝子パネル検査が全国レベルで開始された。また2019年より遺伝子パネル検査に関連した診療の一部が 保険収載された。それらの蓄積された疾患関連ゲノム情報を多くの研究者や医療者が共有・利用（データシェアリン グ）することが求められて㧈り、このことは将来的に頭頸部腫瘍のようにセカンドライン以降のエビデンスの確立され た治療レジメンが少ない領域で有用となることが期待される。

ところでがん遺伝子パネル検查を施行すると、約 1 割の例で生殖細胞系列バリアント（Germline finding）が同定さ れる。がん遺伝子パネル検查で得られた生殖細胞系列バリアント情報を知るメリットとして、1．本人のがん治療方法 の選択に役立つこと、2. 本人の 2 次がん予防、3. 家系員のがん予防への活用が挙げられる。生殖細胞系列バリアント のうち最も高頻度に検出されるのは BRCA1/2 を原因遺伝子とする遺伝性乳がん卵巣がん (Hereditary breast and ovarian cancer：HBOC）である。HBOC は診断、予防、治療の方法がそれぞれ確立され、適切な診療によって確実な がん死低減効果が得られることが分かっている。

ゲノム解析の結果、検出・蓄積された疾患関連ゲノム情報は、国際医学研究としての役割をもつ一方で、生殖細胞系 列バリアントは家系や地域で共有していることから、血縁者としての課題や地域医療としての側面がある。

このようにがんゲノム医療の第 1 の目的はがん患者の指摘治療の選択であるが、ゲノム医療を本質的に普及させるた めには、ゲノム情報を医療者が管理する以前に、遺伝やがんについて当事者や国民が十分理解して、家庭、学校、社会 で語りあうことで国民のゲノムリテラシーの向上を目指すことが重要である。 